\title{
MORPHOPHYSIOLOGICAL RESPONSES OF COWPEA GENOTYPES TO IRRIGATION WATER SALINITY ${ }^{1}$
}

\author{
JOÃO PEDRO ALVES DE AQUINO ${ }^{2}$, ANTÔNIO AÉCIO DE CARVALHO BEZERRA ${ }^{3 *}$, FRANCISCO DE \\ ALCÂNTARA NETO ${ }^{4}$, CARLOS JOSÉ GONCALVES DE SOUZA LIMA ${ }^{5}$, RAYLSON RODRIGUES DE SOUSA ${ }^{2}$
}

\begin{abstract}
Cowpea is broadly cultivated worldwide, especially in semi-arid or arid regions where soil or irrigation water salt contents can negatively influence the species' productive capacity. The objective of this study was to evaluate the morphophysiological responses of cowpea genotypes to irrigation water salinity. The experiment was conducted in a greenhouse, under a completely randomized design with nine replications and in a $5 \times 3$ factorial scheme. Treatments consisted of five levels of irrigation water electrical conductivity - EC $\left(\mathrm{EC}_{0}: 0.55 ; \mathrm{EC}_{1}: 1.60 ; \mathrm{EC}_{2}: 3.20 ; \mathrm{EC}_{3}: 4.80\right.$ and $\mathrm{EC}_{4}: 6.40 \mathrm{dS} \mathrm{m}{ }^{-1}$ ), applied from the 15 th day after sowing (DAS), and three cowpea genotypes (G1: BRS Imponente; G2: MNC04-795F-168 and G3: MNC04-795F-159). EC increases at 35 DAS promoted stem diameter reductions of 8.0\% (G1), 11.4\% (G2), and 7.7\% (G3), indicating different resistance to salinity by each genotype. Leaf area reductions at 25 and $38 \mathrm{DAS}$ were $30.9 \%$ and $38.8 \%$ for $\mathrm{EC}_{0}$ and $\mathrm{EC}_{4}$, respectively. The $\mathrm{BRS}$ Imponente cultivar presented a performance superior to those of G2 and G3 in relation to stem diameter and stem dry matter at 25 DAS, and root-shoot and root-leaf ratios at $38 \mathrm{DAS}$.
\end{abstract}

Keywords: Vigna unguiculata. Saline stress. Plant growth.

\section{RESPOSTAS MORFOFISIOLÓGICAS DE GENÓTIPOS DE FEIJÃO-CAUPI À SALINIDADE DA ÁGUA DE IRRIGAÇÃO}

\begin{abstract}
RESUMO - O feijão-caupi é bastante cultivado no mundo, principalmente em regiões semiáridas ou áridas onde o teor de sais presentes no solo ou na água de irrigação pode influenciar negativamente na capacidade produtiva da espécie. Objetivou-se com o presente trabalho, avaliar as respostas morfofisiológicas de genótipos de feijão-caupi à salinidade da água de irrigação. O experimento foi conduzido em casa de vegetação no delineamento inteiramente casualizado com nove repetições, em esquema fatorial $5 \times 3$, sendo cinco níveis de condutividade elétrica da água de irrigação - $\mathrm{CE}\left(\mathrm{CE}_{0}: 0,55 ; \mathrm{CE}_{1}: 1,60 ; \mathrm{CE}_{2}: 3,20 ; \mathrm{CE}_{3}: 4,80\right.$ e $\mathrm{CE}_{4}$ : $6,40 \mathrm{dS} \mathrm{m}^{-1}$ ) aplicados a partir do $15^{\circ}$ dia após a semeadura (DAS) e três genótipos de feijão-caupi (G1: BRS Imponente; G2: MNC04-795F-168 e G3: MNC04-795F-159). Aumentos nas CE aos 35 DAS, promoveram reduções no diâmetro do caule de 8,0\% (G1), 11,4\% (G2) e 7,7\% (G3) indicando resistências diferenciadas dos genótipos aos efeitos da salinidade. Entre $\mathrm{CE}_{0}$ e $\mathrm{CE}_{4}$ as reduções na área foliar aos 25 e 38 DAS foram de $30,9 \%$ e $38,8 \%$, respectivamente. Os efeitos negativos da salinidade foram mais intensos nas matérias secas da raiz e da haste, aos 20 DAS e na matéria seca das folhas, aos 30 DAS. A cultivar BRS Imponente apresenta desempenho superior a G2 e G3 em relação ao diâmetro do caule e matéria seca da haste, aos 25 DAS, e razão parte aérea raiz e folha raiz, aos 38 DAS.
\end{abstract}

Palavras-chave: Vigna unguiculata. Estresse salino. Crescimento da planta.

\footnotetext{
${ }^{*}$ Corresponding author

${ }^{1}$ Received for publication in $08 / 07 / 2016$; accepted in $03 / 06 / 2017$.

Paper approved from IV CONAC 2016.

Paper extracted from the master's thesis of the first author, supported by CAPES.

${ }^{2}$ Universidade Federal do Piauí, Teresina, PI, Brazil; aquinojpa.agro@gmail.com, rayr-80@hotmail.com.

${ }^{3}$ Department of Agricultural Policy and Planning, Universidade Federal do Piauí, Teresina, PI, Brazil; aecio@ufpi.edu.br.

${ }^{4}$ Department of Plant Science, Universidade Federal do Piauí, Teresina, PI, Brazil; fneto@ufpi.edu.br.

${ }^{5}$ Department of Agricultural Engineering and Soil Science, Universidade Federal do Piauí, Teresina, PI, Brazil; carloslima@ufpi.edu.br.
} 


\section{INTRODUCTION}

The cowpea [Vigna unguiculata (L.) Walp.] tends to play an increasingly important role in the food security of the peoples from tropical and subtropical regions with high pluviometric instability, and low technological level. It is considered of high nutritional value, easy to produce, and accessible. Therefore the cowpea is one of the main food crops, especially for low-income populations historically characterized by the deficiency of energy-protein and minerals (BEZERRA et al., 2014).

Cowpea is cultivated predominantly in the semi-arid in Brazil, where edaphoclimatic and water conditions are very favorable to the occurrence of soil salinization and/or irrigation water. Abiotic factors such as drought and salinity are major plant stressors and can cause significant damage to crop development and yield. According to Coelho et al. (2014), salinity in soil or water negatively influences the plants' ability to absorb water and causes metabolic changes similar to those of water deficit.

Chaum et al. (2013) evaluated tolerance levels to saline stress in legumes and highlighted the negative effects of salinity on height, dry matter of shoots and roots, leaf area, and efficient water use in cowpea. Assis Júnior et al. (2007) and Calvet et al. (2013) emphasize that excess of salts can compromise the plants' physiological and biochemical functions, causing osmotic stress, which results in disturbed water relations, absorption alterations, essential nutrients usage, and toxic ions accumulation.

Dantas et al. (2002) reported that this tolerance degree to salinity may vary according to the cultivar, the plant development stage, the exposure time to saline stress, the edaphoclimatic conditions, and the irrigation management. They also point out that $6.0 \mathrm{dS} \mathrm{m}^{-1}$ is the water salinity level most suitable for comparative evaluations among cowpea genotypes. Almeida et al. (2011) identified cowpea genotypes moderately tolerant and moderately susceptible to various levels of irrigation water salinity, indicating the existence of genetic variability and the possibility of selecting tolerant genotypes.

This study aims to evaluate the morphophysiological responses of cowpea genotypes to irrigation water salinity.

\section{MATERIAL AND METHODS}

The experiment was conducted from June to August 2015, in a greenhouse in the Experimental Area of the Plant Science Department, Agricultural Sciences Research Center, Federal University of Piauí. The area is located in the city of Teresina-PI, at $05^{\circ} 04^{\prime} 35^{\prime \prime}$ South, $42^{\circ} 78^{\prime} 38^{\prime \prime}$ West, and altitude of $72 \mathrm{~m}$. According to Thornthwaite and Mather (1955), the local climate is C1sA'a', characterized as dry sub humid, megathermal, with moderate water surplus in the summer. The average annual rainfall is 1,343.4 mm, concentrated between January and April, with an average temperature of $28.2{ }^{\circ} \mathrm{C}$, and the mean relative air humidity is $69.7 \%$ (BASTOS, ANDRADE JÚNIOR, 2014).

Cultivation was carried out in $3.8 \mathrm{dm}^{3}$ plastic pots filled with eutrophic Red-Yellow Ultisol, with sandy texture, collected in the layer of 0.00 to $0.20 \mathrm{~m}$, and according to its chemical characterization (Table 1), fertilization with ammonium sulfate $\left(20 \mathrm{~kg}\right.$ of $\left.\mathrm{N} \mathrm{ha}^{-1}\right)$, triple superphosphate $\left(60 \mathrm{~kg}\right.$ of $\left.\mathrm{P}_{2} \mathrm{O}_{5} \mathrm{ha}^{-1}\right)$, and potassium chloride $\left(70 \mathrm{~kg}\right.$ of $\left.\mathrm{K}_{2} \mathrm{O} \mathrm{ha}^{-1}\right)$ was performed. Pots were arranged in three rows with 15 pots each, on galvanized steel benches $1.2 \mathrm{~m}$ wide, $5.0 \mathrm{~m}$ long and $0.8 \mathrm{~m}$ high. The spacing between and within rows was 0.30 and $0.22 \mathrm{~m}$, respectively.

Table 1. Chemical characterization of the soil used for pot filling.

\begin{tabular}{|c|c|c|c|c|c|c|c|c|c|c|c|}
\hline \multirow{2}{*}{$\begin{array}{c}\mathrm{pH} \\
\mathrm{H}_{2} \mathrm{O}\end{array}$} & \multirow{2}{*}{$\begin{array}{c}\mathrm{OM} \\
\%\end{array}$} & $\mathrm{P}$ & $\mathrm{K}$ & $\mathrm{Na}$ & $\mathrm{Mg}^{+2}$ & $\mathrm{Ca}^{+2}$ & $\mathrm{Al}^{+3}$ & $\mathrm{H}+\mathrm{Al}$ & SB & CTC & \multirow{2}{*}{$\begin{array}{l}\mathrm{V} \\
\%\end{array}$} \\
\hline & & \multicolumn{3}{|c|}{--------- $\mathrm{mg} \mathrm{dm}^{-3}$---------- } & \multicolumn{6}{|c|}{------------- $\mathrm{cmol}_{\mathrm{c}} \mathrm{dm}^{-3}$--------------- } & \\
\hline 6.8 & 1.3 & 1.5 & 19.7 & 12.3 & 0.50 & 1.9 & 0.0 & 1.5 & 2.5 & 4.0 & 62.3 \\
\hline
\end{tabular}

Source: UFPI Laboratory of Soil Analyses.

Seeds were treated with fipronil + methyl thiophanate + pyraclostrobin at a dosage of $200 \mathrm{~mL}$ for $100 \mathrm{~kg}$ of seeds. The sowing was done on June $22^{\text {nd }}, 2015$ with five seeds per pot and the thinning ten days after sowing (DAS), leaving only one plant per pot. At 15 DAS, cover fertilization with ammonium sulfate was carried out at a dosage of $10 \mathrm{~kg}$ of $\mathrm{N} \mathrm{ha}^{-1}$.

A completely randomized design with nine replicates in the $5 \times 3$ factorial scheme was used, with five levels of irrigation water electrical conductivity - $\mathrm{EC}\left(\mathrm{EC}_{0}: 0.55 ; \mathrm{EC}_{1}: 1.60 ; \mathrm{EC}_{2}\right.$ : 3.20; $\mathrm{EC}_{3}: 4.80$ and $\mathrm{EC}_{4}: 6.40 \mathrm{dS} \mathrm{m} \mathrm{m}^{-1}$ ), and three elite northern Embrapa cowpea genotypes (G1: BRS Imponente; G2: MNC04-795F-168 and G3: MNC04-795F-159). Water from the Department of Phytotechnology was used in the experiment, and it presented $\mathrm{EC}$ of $0.55 \mathrm{dS} \mathrm{m} \mathrm{m}^{-1}$, corresponding to $\mathrm{EC}_{0}$ 
level.

A salinity curve was constructed from dilutions of 0.1 to $5.0 \mathrm{~g} \mathrm{NaCl}$ in $1 \mathrm{~L}$ water, with an addition interval of $0.1 \mathrm{~g} \mathrm{NaCl}$, totaling 50 concentrations. The electrical conductivity of solutions ( $\left.\mathrm{dS} \mathrm{m} \mathrm{m}^{-1}\right)$ was used to adjust the salinity curve equation (Figure 1). The amount of $\mathrm{NaCl}$ to be diluted per liter of water to obtain the five pre-established levels of irrigation water electrical conductivity was determined from this equation.

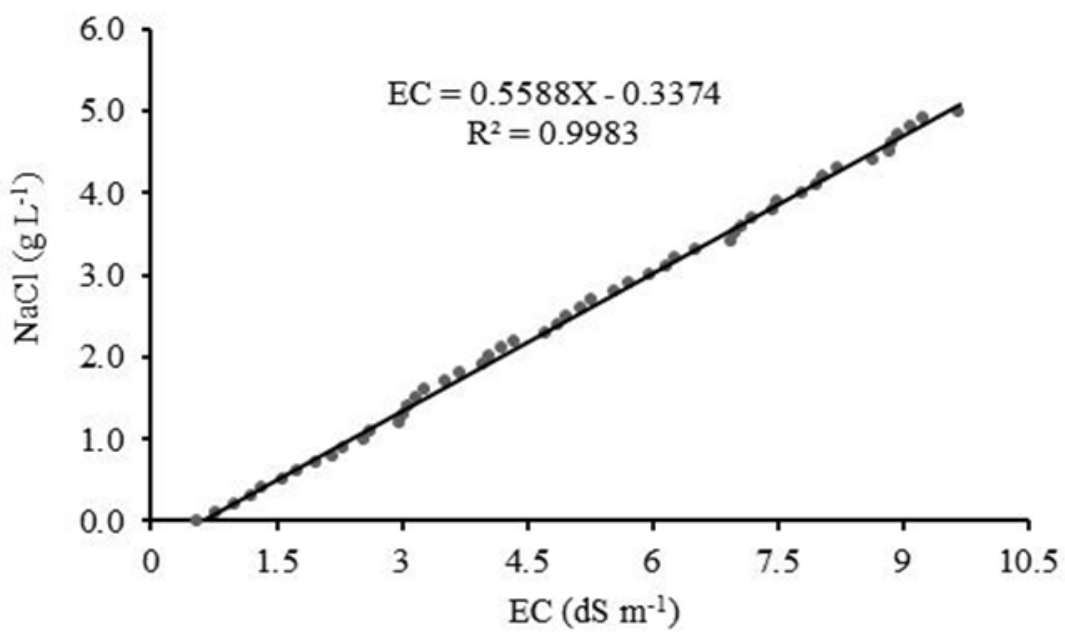

Figure 1. Salinization curve as a function of $\mathrm{NaCl}$ concentration.

Before planting, water was added to the soil until it reached its field capacity. Irrigations were performed manually by using a graduated cylinder, and $100 \%$ of the evapotranspiration water was replenished in two daily applications, $60 \%$ in the morning and $40 \%$ in the afternoon. The water mass to be replenished was determined by the difference in the weighing of three pots per bench referring to $\mathrm{EC}_{0}$ combined with each genotype, before and after water application (Equation 1). Irrigation occurred in the period from 15 to $45 \mathrm{DAS}$, according to the specified salinity levels.

$$
\mathrm{DWM}=\mathrm{PMB}-\mathrm{PMA}
$$

In which,

DWM: daily water mass to be replaced, in $\mathrm{kg}$. PMB: pot mass, in $\mathrm{kg}$, before irrigation.

PMA: pot mass, in $\mathrm{kg}$, after irrigation.

The following non-destructive samples were evaluated at 25 and 35 DAS: stem diameter (SD, in $\mathrm{mm}$ ), which was measured with a digital caliper immediately below the cotyledon node; plant height $(\mathrm{PH}$, in $\mathrm{cm})$, measured between the cotyledon node and the apical bud and number of nodes in the main branch (NNMB).

Three randomly selected plants of each treatment were separated into leaves, stems, and roots in the destructive samples at 25 and $38 \mathrm{DAS}$, to determine the characteristics: leaf area $\left(\mathrm{LA}\right.$, in $\left.\mathrm{cm}^{2}\right)$, obtained with leaf area integrator LICOR, model LI-3100; dry matter of leaves (DML), stems (DMS), and roots (DMR) in grams; root shoot ratio (RSR - Equation 2), and root leaf ratio (RLR - Equation 3). To determine the dry matter, the parts were individually packed in paper bags and dried in an oven with forced air circulation at $65^{\circ} \mathrm{C}$ until reaching constant dry matter, and then weighed in precision scales $(0.01 \mathrm{~g})$.

$$
\begin{aligned}
& \mathrm{RSR}=\frac{\mathrm{DML}+\mathrm{DMS}}{\mathrm{DMR}} \quad\left(\mathrm{g} \mathrm{g}^{-1}\right) \\
& \mathrm{RFR}=\frac{\mathrm{DML}}{\mathrm{DMR}}\left(\mathrm{g} \mathrm{g}^{-1}\right)
\end{aligned}
$$

The data were submitted to analysis of variance with polynomial regression for the water salinity levels and the genotypes' means were compared by the Tukey test $(5 \%)$. The analyses were performed using the ASSISTAT statistical software (version 7.7).

\section{RESULTS AND DISCUSSION}

The results of the Tukey test for the genotypes' means when the interaction between factors was non-significant $(\mathrm{p}>0.05)$ are presented in Figure 2. 

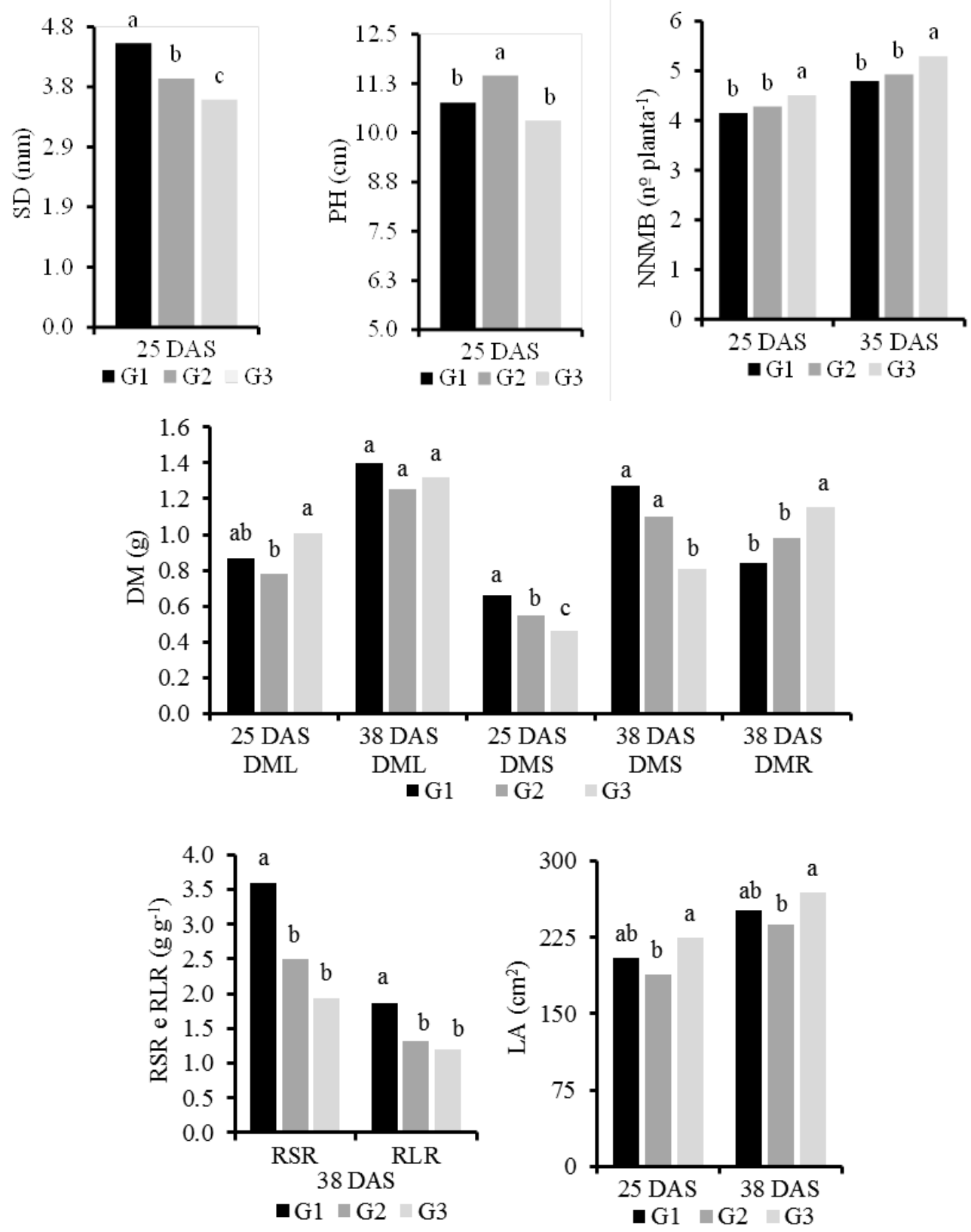

Figure 2. Means by genotype ${ }^{1}$ for stem diameter (SD), plant height $(\mathrm{PH})$, number of nodes in the main branch (NNMB) at 25 and/or 35 days after sowing (DAS), dry matter of leaves (DML), stems (DMS) and roots (DMR), root shoot ratio (RSR), root leaf ratio (RLR) and leaf area (LA) at 25 and/or 38 DAS. Teresina, PI, 2016. ${ }^{1}$ G1: BRS Imponente; G2: MNC04-795F-168 and G3: MNC04-795F-159. Genotypes with the same letter do not differ by Tukey test ( $<<0.05)$.

There was a significant difference between the genotypes for SD, and BRS Imponente (G1) presented the highest mean $(4.49 \mathrm{~mm})$. Greater SD, especially at the epicotyl level, may favor resistance to lodging since according to Bezerra et al. (2012), plants break in the epicotyl region in the occurrence of lodging.

At 25 DAS, G2 presented the highest PH and differed significantly from the other genotypes. Presenting a higher mean initial development under saline stress conditions may favor the genotype in the competition for environmental and technological factors in the subsequent stages.

G3 presented NNMB at 25 and 35 DAS and
DMR at 38 DAS significantly higher than the other genotypes, and LA and DML higher than G2 at 25 and/or 38 DAS. Chaum et al. (2013) observed negative effects of salinity on plant height, leaf area and plant dry matter in cowpea.

At 38 DAS, BRS Imponente (G1) and G2 presented the highest DMS, showing better stem structure (stems), while G3's root development (DMR) was higher than G1 and G2.

RSR and LSR were significantly higher for BRS Imponente (G1) than were for G2 and G3, indicating a higher relative participation of shoots and leaves in these two relations. This difference may favor G1 under normal cultivation conditions 
because it presents a greater photosynthetic structure.

EC increases promoted significant linear reductions of $7.9 \%$ in $\mathrm{SD}$ when compared to $\mathrm{EC}_{0}$ and $\mathrm{EC}_{4}$ in the average of the three genotypes at $25 \mathrm{DAS}$. At 35 DAS, the differentiated SD reductions by genotypes were $8.0 \%(\mathrm{G} 1), 11.4 \%(\mathrm{G} 2)$ and $7.7 \%$ (G3), demonstrating that the negative influence of EC increases occurs in both development stages; however, at 35 DAS genotypes respond differently, and may indicate greater or lesser resistance to the negative effects of EC increases on SD (Figure 3).

$\mathrm{PH}$ and $\mathrm{NNMB}$ presented significant linear reductions of 5.12 and $14.9 \%$ for $\mathrm{EC}_{0}$ and $\mathrm{EC}_{4}$ at 25 DAS, respectively, being of 7.7 and $17.3 \%$, respectively, at 35 DAS (Figure 3). The negative effects were observed to be intensified in $50.7 \%$ in $\mathrm{PH}$ and $16.1 \%$ in NNMB when compared at 25 and 35 DAS, indicating a tendency of cumulative
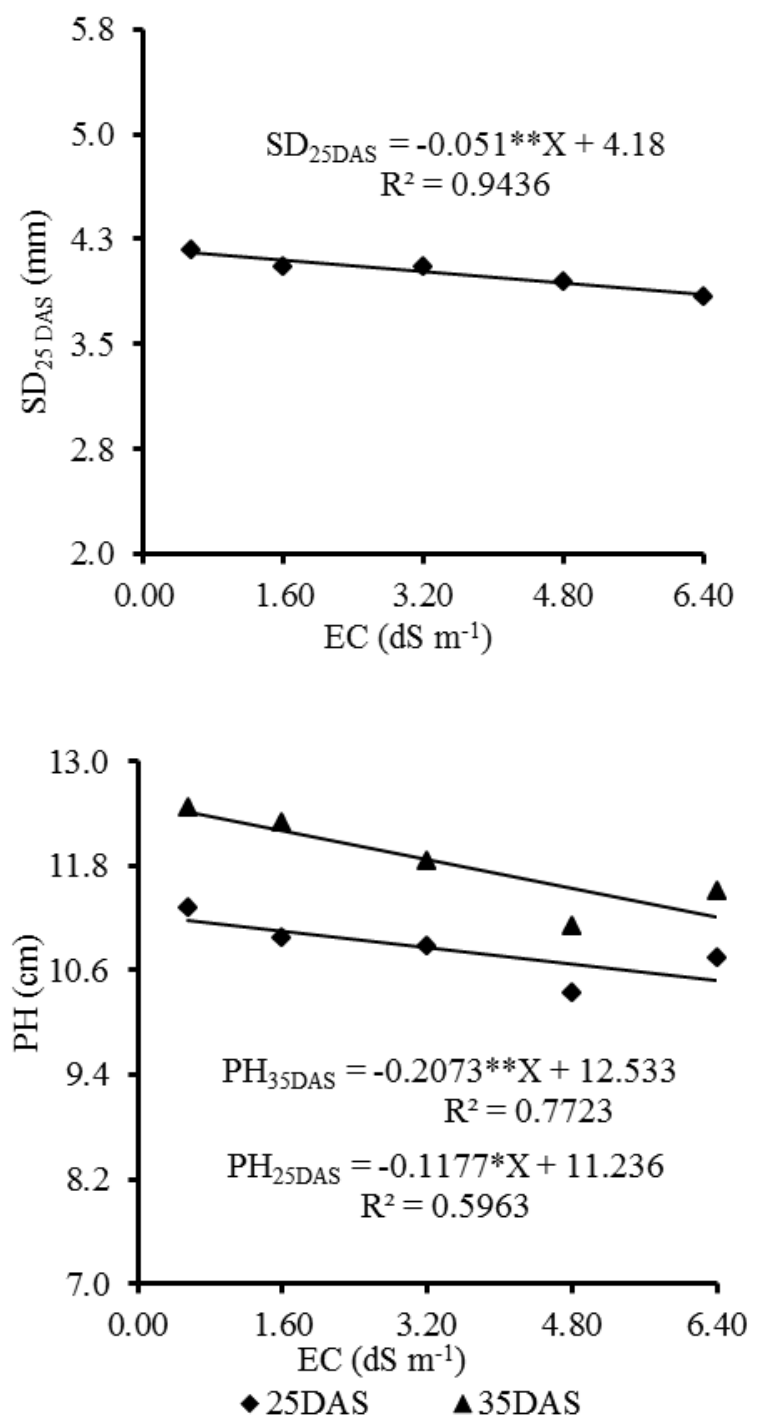

negative effect, which can become more drastic in the reproductive phase.

Brito et al. (2015) worked with different cowpea genotypes irrigated with saline water and obtained reductions of more than $20 \%$ for $\mathrm{PH}$ among genotypes irrigated with water supply, with a conductivity of $4.8 \mathrm{dS} \mathrm{m}^{-1}$. Andrade et al. (2013) worked in a greenhouse with initial growth of cowpea genotypes and found a decrease in the SD of the plant undergoing saline stress at 35 DAS, with reductions above 21\%. Dias and Blanco (2010) attributed the reductions in the growth parameters $\mathrm{SD}, \mathrm{NNMB}$ and $\mathrm{PH}$ to the indirect effects caused by water absorption difficulty, specific ion toxicity, ion interference in the physiological processes and ions resulting from the excessive accumulation of water salts which were fixed in the more superficial layers of the soil with time, under low leaching rate.
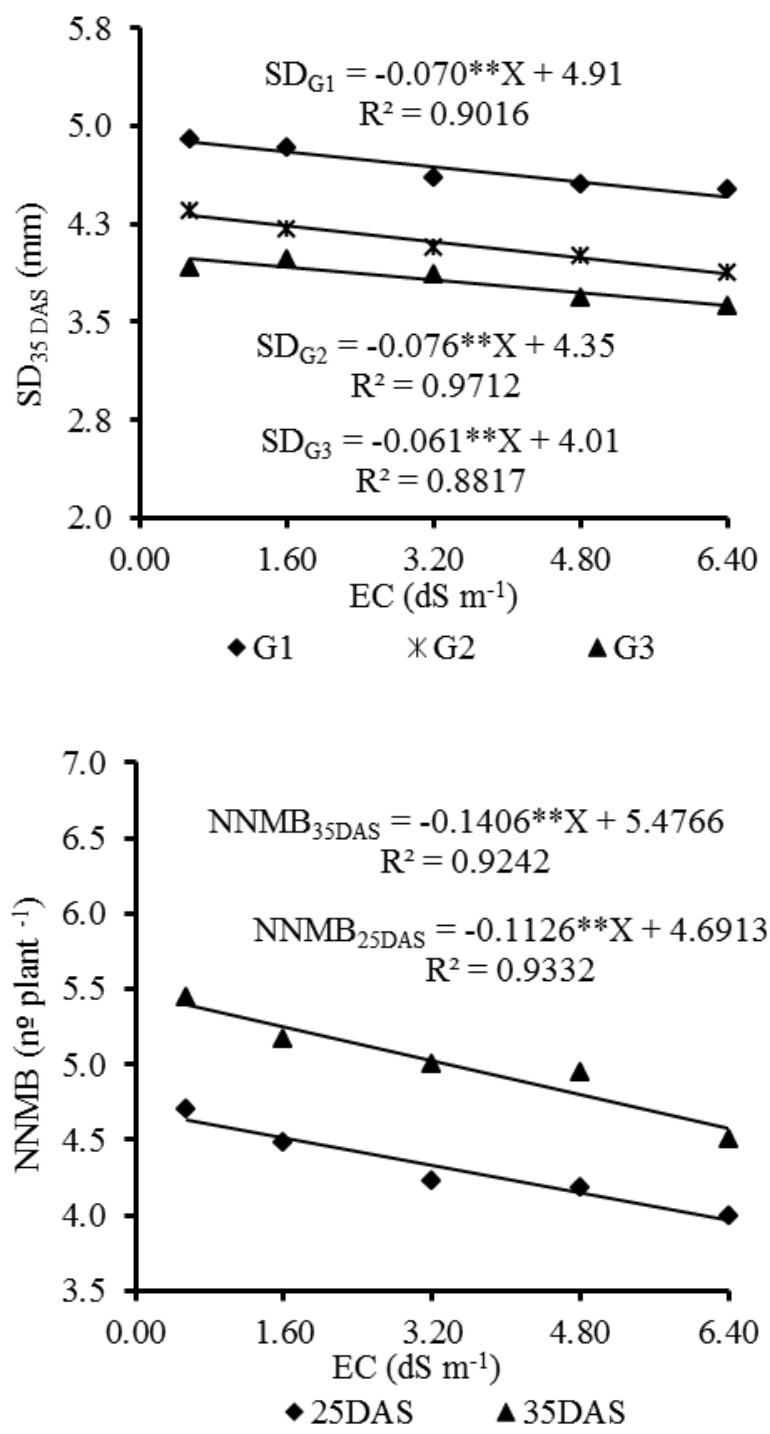

Figure 3. Stem diameter (SD), plant height (PH) and number of nodes in the main branch (NNMB) at 25 and 35 days after sowing (DAS), in three cowpea genotypes submitted to five levels of irrigation water electrical conductivities of (EC). 
The dry matter of leaves (DML), stems (DMS) and roots (DMR) presented significant reductions in response to $\mathrm{EC}$ increases in both periods (25 and 38 DAS) (Figure 4). When comparing the responses to $\mathrm{EC}_{0}$ and $\mathrm{EC}_{4}$ at $25 \mathrm{DAS}$, the highest reductions were observed in DMR, being $70.1 \%$ in $\mathrm{G} 1$ and $\mathrm{G} 2$, and $77.6 \%$ in $\mathrm{G} 3$, while for DML and DMS the mean reductions in the three

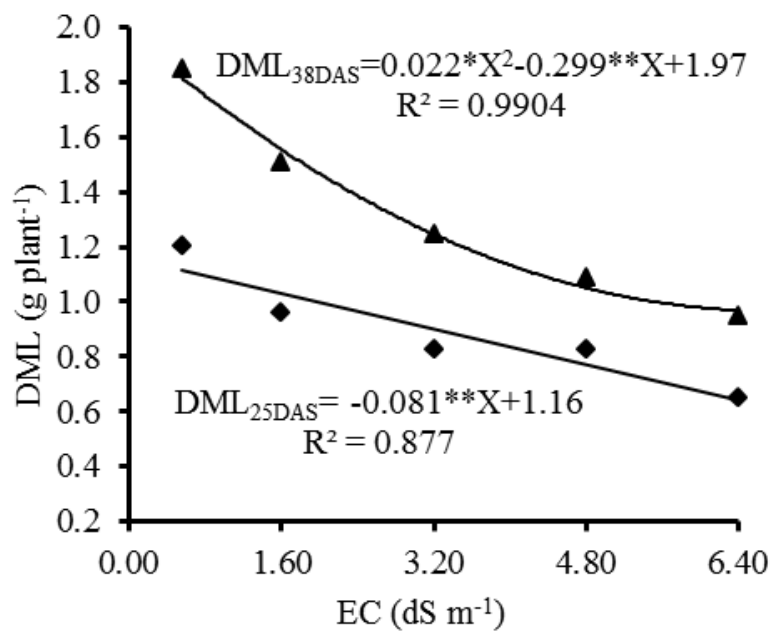

$\bullet 25$ DAS $\Delta 38$ DAS

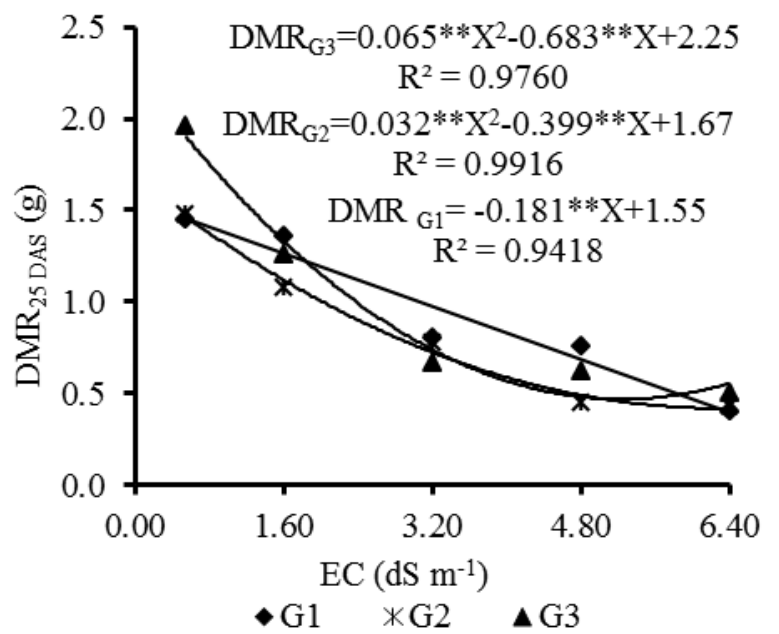

genotypes were 45.8 and $44.2 \%$, respectively. At 38 DAS, reductions were $60.9 \%$ (DMR), $48.7 \%$ (DML), and $37.2 \%$ (DMS). When comparing 25 and 38 DAS, there was a decrease in the intensity of DMR reductions of $16.1 \%$ and in DMS of $15.8 \%$, while for DML there was an increase of $6.2 \%$ in the intensity of reduction.

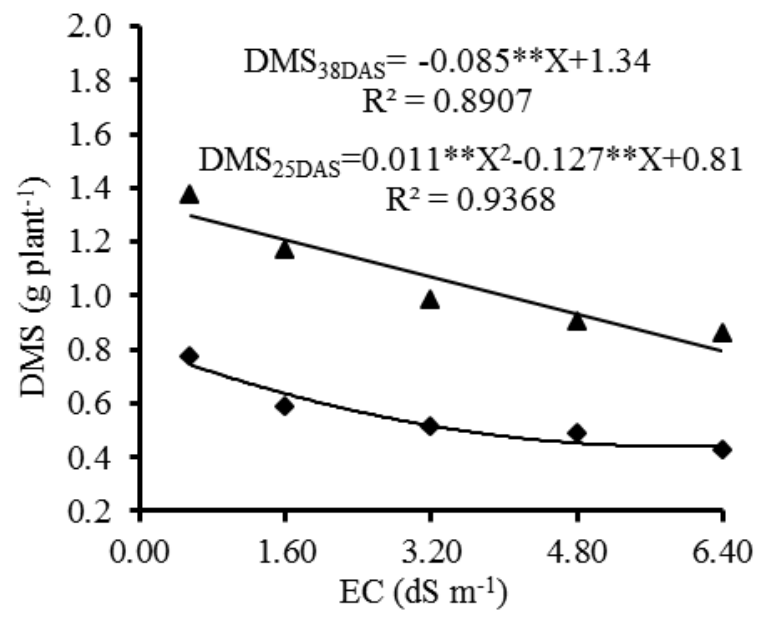

$\bullet 25 \mathrm{DAS} \Delta 38 \mathrm{DAS}$

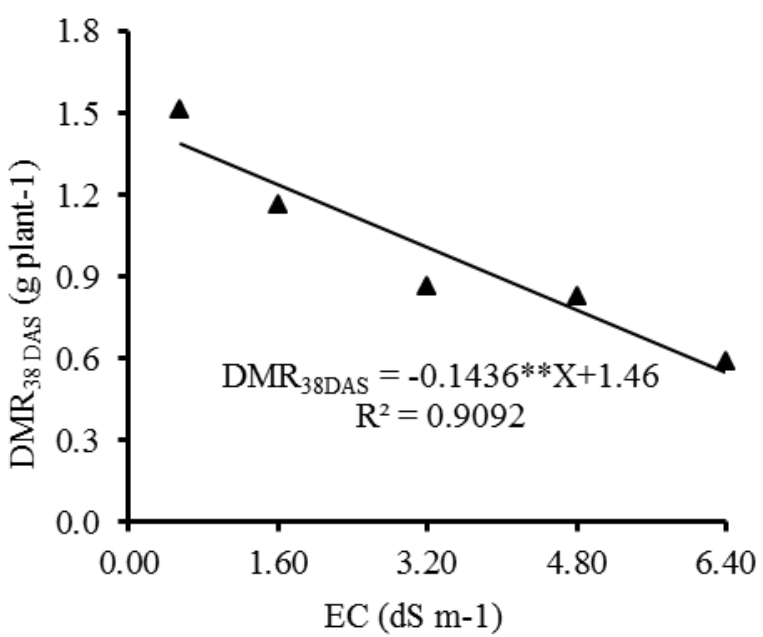

Figure 4. Dry matter of leaves (DML), stems (DMS) and roots (DMR) of the three cowpea genotypes submitted to five levels of irrigation water electrical conductivity (EC) at 25 and 38 days after sowing (DAS).

Silva et al. (2009) and Oliveira et al. (2013) worked with cowpea genotypes subjected to saline stress and verified a reduction in the dry matter of leaves, stem, root and total dry matter when submitted to EC increases. Sousa et al. (2010) evaluated the morphophysiological responses of some saline-stressed crops, including cowpea, and found reductions in dry matter of aerial part $(69.0 \%)$ and DMR $(79.0 \%)$, with EC, increases up to $8.0 \mathrm{dS} \mathrm{m}^{-1}$.

There were significant linear increases in RSR $(42.7 \%)$ and LSR (31.2\%) in response to EC increases from 0.55 to $6.40 \mathrm{dS} \mathrm{m}^{-1}$ (Figure 5). These increases confirm that the negative effects on biomass in response to EC increases occurred more intensely in the roots, which presented a mean reduction of $66.8 \%$ in DMR, while for DML and DMS the average reductions were respectively $47.2 \%$ and $40.7 \%$, also considering 25 and 38 DAS.

Souza et al. (2007) evaluated cowpea under saline stress and reported RSR increase with CE increases. Lima et al. (2007) reported that the root shoot ratio in response to saline stress is very variable in different plant species, and Lutts, Kinet, and Bouharmont (1996) considered the root shoot ratio to be indicative of tolerance to abiotic stresses. 

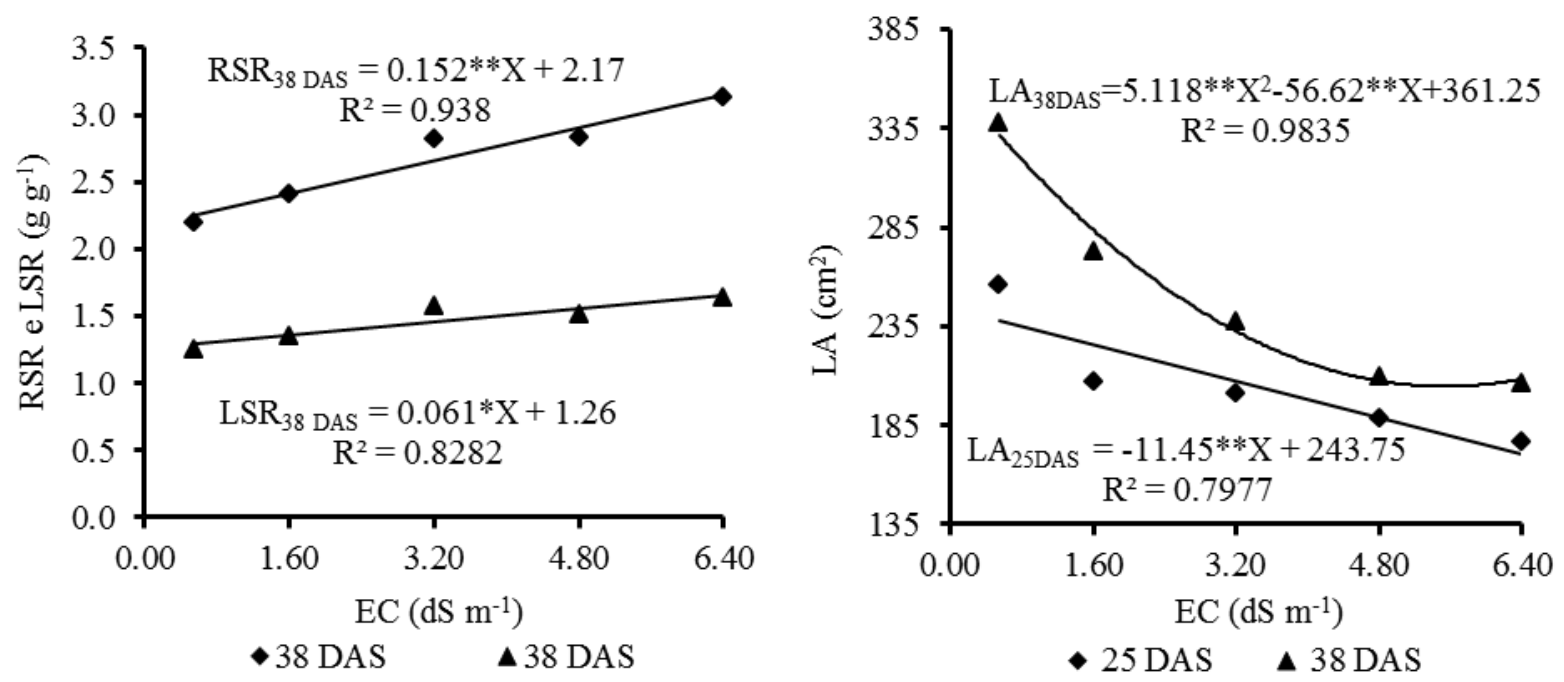

Figure 5. Root shoot ratio (RSR), leaf root ratio (LSR) and leaf area (LA) of three cowpea genotypes at 25 and 38 days after sowing (DAS), submitted to five levels of irrigation water electrical conductivity (EC).

EC increases promoted linear decreases in LA at $25 \mathrm{DAS}$, and quadratic at $38 \mathrm{DAS}$. Considering the interval between $\mathrm{EC}_{0}$ and $\mathrm{EC}_{4}$, the reductions in LA at 25 and 38 DAS were $30.9 \%$ and $38.8 \%$, respectively (Figure 5). From the total reduction at 38 DAS, 76.8\% occurred when EC was increased from $0.55\left(\mathrm{EC}_{0}\right)$ to $3.20\left(\mathrm{EC}_{3}\right) \mathrm{dS} \mathrm{m} \mathrm{m}^{-1}$. This data indicates an intensification of the negative effects of EC increases at more advanced stages of genotype development. The significant reductions in biomass and leaf area at 25 and 38 DAS in response to EC increases could negatively impact plant productive potential.

Xavier et al. (2014) evaluated cowpea submitted to irrigation with saline water and nitrogen fertilization and observed a $33.72 \%$ reduction in LA at the level of $4.5 \mathrm{dS} \mathrm{m}^{-1}$ of irrigation water. According to Oliveira et al. (2012) and Feitosa et al. (2015), there are morphological and anatomical alterations, and also leaf area reductions for the maintenance of high water potential in plants submitted to saline stress.

\section{CONCLUSIONS}

The increase in irrigation water salinity negatively influenced the morphophysiological characteristics evaluated, promoting significant reductions in stem diameter, plant height and number of nodes in the main branch at 25 and 35 days after sowing (DAS), and more intense reductions in the dry matter of roots than of shoots at 25 and 38 DAS. The BRS Imponente cultivar presented superior performance than $\mathrm{G} 2$ and $\mathrm{G} 3$ in relation to stem diameter and dry matter at $25 \mathrm{DAS}$, and root shoot ratio and root leaf ratio at $38 \mathrm{DAS}$.

\section{REFERENCES}

ALMEIDA, W. S. et al. Identificação de genótipos de feijão-caupi tolerantes a salinidade avaliado por meio de método multivariado. Ciência Rural, Santa Maria, v. 41, n. 11, p. 1884-1889, 2011.

ANDRADE, J. R. et al. Crescimento inicial de genótipos de feijão-caupi submetidos a diferentes níveis de água salina. Agropecuária Científica no Semiárido, Patos, v. 9, n. 4, p. 38-43, 2013.

ASSIS JÚNIOR J. O. et al. Produtividade do feijão-caupi e acúmulo de sais no solo em função da fração de lixiviação e da salinidade da água de irrigação. Revista Brasileira de Engenharia Agrícola, Jaboticabal, v. 27, n. 3, p. 702-713, 2007.

BASTOS, E. A.; ANDRADE JÚNIOR, A. S. Boletim Agrometeorológico do ano de 2013 para o município de Teresina, PI. Teresina: Embrapa Meio-Norte, 2014. 39 p. (Documentos, 228).

BEZERRA, A. A. C. et al. Comportamento morfoagronômico de feijão-caupi, cv. BRS Guariba, sob diferentes densidades de plantas. Revista Ciência Agrárias, Belém, v. 55, n. 3, p. 184-189, 2012.

BEZERRA, A. A. C. et al. Morfofisiologia e produção de feijão-caupi, cultivar BRS Novaera, em função da densidade de plantas. Revista Caatinga, Mossoró, v. 27, n. 4, p. 135-141, 2014.

BRITO, K. Q. D. et al. Crescimento de genótipos de feijão-caupi irrigados com água salina. Revista Verde de Agroecologia e Desenvolvimento Sustentável, Mossoró, v. 10, n. 5, p. 16-22, 2015. 
CALVET, A. S. F. et al. Crescimento e acumulação de solutos em feijão-caupi irrigado com águas de salinidade crescente em diferentes fases de desenvolvimento. Irriga, Botucatu, v. 18, n. 1, p. 148-159, 2013.

CHAUM, S. et al. Physiomorphological changes of cowpea (Vigna unguiculata (L.) Walp.) and jack bean (Canavalia ensiformis (L.) DC.) in responses to soil salinity. Australian Journal of Crop Science, Melbourne, v. 7, n. 13, p. 2128-2135, 2013.

COELHO, J. B. et al. Ponto de murcha permanente fisiológico e potencial osmótico de feijão-caupi cultivado em solos salinizados. Revista Brasileira de Engenharia Agrícola e Ambiental, Campina Grande, v. 18, n. 7, p. 708-713, 2014.

DANTAS, J. P. et al. Avaliação de genótipos de caupi sob salinidade. Revista Brasileira de Engenharia Agrícola e Ambiental, Campina Grande, v. 6, n. 3, p. 425-430, 2002.

DIAS, N. S.; BLANCO, F. F. Efeitos dos sais no solo e na planta. In: GHEYI, H. R.; DIAS, N. S.; LACERDA, C. F. (Eds.). Manejo da salinidade na agricultura: estudos básicos e aplicados. Fortaleza: INCTSal, 2010. v. 1, cap. 9, p. 129-141.

FEITOSA, S. O. et al. Crescimento do feijão-caupi irrigado com efluente tratado e água salina sob diferentes concentrações. Revista Agropecuária Técnica, Areia, v. 36, n. 1, p. 146-155, 2015.

LIMA, C. J. G. S. et al. Resposta do feijão-caupi a salinidade da água de irrigação. Revista verde de agroecologia e desenvolvimento sustentável, Pombal, v. 2, n. 2, p. 79-86, 2007.

LUTTS, S.; KINET, J. M.; BOUHARMONT, J. Effects of salt stress on growth, mineral nutrition and proline accumulation in relation to osmotic adjustment in rice (Oryza sativa L.) cultivars differing in salinity resistance. Plant Growth Regulation, Amsterdam, v. 19, n. 3, p. 207-218, 1996.

OLIVEIRA, F. A. et al. Desenvolvimento inicial do maxixeiro irrigado com água de diferentes salinidades. Agropecuária Científica no Semiárido, Patos, v. 8, n. 2, p. 22-28, 2012.

OLIVEIRA, F. A. et al. Interação entre salinidade e bioestimulante na cultura do feijão-caupi. Revista Brasileira de Engenharia Agrícola e Ambiental, Campina Grande, v. 17, n. 5, p. 465-471, 2013.

SILVA, F. E. O. et al. Desenvolvimento vegetativo de feijão-caupi irrigado com água salina em casa de vegetação. Revista Caatinga, Mossoró, v. 22, n. 3, p. $156-159,2009$.

SOUSA, C. H. C. et al. Respostas morfofisiológicas de plantas de sorgo, feijão-de-corda e algodão sob estresse salino. Revista Agropecuária Técnica, Areia, v. 31, n. 2, p. 29-36, 2010.

SOUZA, R. A. et al. Crescimento e nutrição mineral de feijão-de-corda em função da salinidade e da composição iônica da água de irrigação. Revista Brasileira de Ciências Agrárias, Recife, v. 2, n. 1, p. $75-82,2007$.

THORNTHWAITE, C. W.; MATHER, J. R. The water balance. Publications in Climatology. New Jersey: Drexel Institute of Technology, 1955. $104 \mathrm{p}$.

XAVIER, D. A. et al. Irrigação com água salina e adubação com nitrogênio no cultivo do feijão-caupi. Revista Verde de Agroecologia e Desenvolvimento Sustentável, Pombal, v. 9, n. 3, p. 131-136, 2014. 